\title{
Goa Displayed in Goa: The 1860 Industrial Exhibition of Portuguese Colonial India
}

Goa exposta em Goa: a Exposição Industrial da Índia Colonial Portuguesa em 1860

Goa exposée à Goa: L'Exposition Industrielle de l'Inde Coloniale Portugaise en 1860

Filipa Lowndes Vicente

\section{(2) OpenEdition}

\section{Journals}

Electronic version

URL: http://journals.openedition.org/rccs/7039

DOI: $10.4000 /$ rccs.7039

ISSN: 2182-7435

\section{Publisher}

Centro de Estudos Sociais da Universidade de Coimbra

Printed version

Date of publication: 1 May 2018

Number of pages: 159-182

ISSN: 0254-1106

\section{Electronic reference}

Filipa Lowndes Vicente, « Goa Displayed in Goa: The 1860 Industrial Exhibition of Portuguese Colonial India », Revista Crítica de Ciências Sociais [Online], 115 | 2018, Online since 15 May 2018, connection on 19 April 2019. URL : http://journals.openedition.org/rccs/7039; DOI : 10.4000/rccs.7039 


\section{FILIPA LOWNDES VICENTE}

\section{Goa Displayed in Goa: The 1860 Industrial Exhibition of Portuguese Colonial India}

In 1860, Goa hosted the Industrial Exhibition of Portuguese India with 230 exhibitors and over 4,000 articles on display, all described in a comprehensive printed catalogue. How can we explain that Goa, considered the most neglected Portuguese colony by the late 19th century, had an "industrial exhibition" five years before the first international exhibition to take place in Portugal, in 1865 , and twenty years before the first exhibition held in a Portuguese colony, that of Cape Verde, in 1881? This article tries to understand the meaning of a local initiative that led to the display of Goa's entangled past, present, and future - a space which was 'displayed' across time and described by many as a "country", with its own identity, and separate from the "other" India.

Keywords: exhibitions; Goa; Goa history; Industrial Exhibition of Portuguese India (1860); modernity.

\section{Introduction}

In 1860, Goa was the setting for an exhibition that had the word "Industry" in its title - the Exposição Industrial da Índia Portuguesa [Industrial Exhibition of Portuguese India]. In this exhibition there were 230 exhibitors and almost 4,000 articles on display, all described in a comprehensive printed catalogue. ${ }^{1}$ How can we explain how Goa, considered throughout the second half of the 19th century to be the most neglected Portuguese colony, had an "industrial exhibition" five years before the first international exhibition that took place in Portugal in 1865 and twenty years before the first exhibition to be held in a Portuguese colony, that of Cape Verde, in 1881? The pieces of machinery or the manufactured goods, symbols of the industrialisation that the exhibition was supposed to showcase, were barely visible and proved unable to counter

\footnotetext{
${ }^{1}$ Relatório e catálogo da Exposição Industrial da Índia Portuguesa no anno de 1860 (1860). Nova
} Goa: Imprensa Nacional. From now on mentioned as Relatório e catálogo da Exposição Industrial. 
the overwhelming presence of natural products ranging from medicinal herbs to staple foods and crafts for domestic, religious or purely decorative use. Independently of what was actually on exhibition, the local initiative of organising an event that put together the words "exhibition", "industrial" and "Portuguese India" was quite relevant in and of itself. An analysis of the catalogue listings also reveals how past, present, and future could be intertwined, mutually engaged in a wider narrative in which the main subject was "Goa" - a single space depicted over time and described as a "country" in the printed sources related to the exhibition.

The Industrial Exhibition opened just after the closing of another kind of exhibition, which in Portuguese uses the same word, "exposição": the 1859 temporary public religious exposition of the sainted relics of Asia's most famous Christian figure, St. Francis Xavier (Gupta, 2014; Vicente, 2002). Both events took place in Old Goa, the former capital of the Portuguese Indian Empire as this was the location of the Bom Jesus Church, where the Catholic relic was kept. In the nineteenth century, however, Old Goa was no longer an urbanised and populated city, owing to the official move of the capital to Pangim in the eighteenth century. Pilgrims to the sacred Catholic site could thus become exhibition goers, attending the two consecutive events that could well be thought of as a metaphor for the multiple identities, not necessarily contradictory ones, that Goa was forging in the second half of the nineteenth century, ones addressing its past role as the Christian centre of Asia and its "imagined" present and future role as a place for commerce and economic exploration.

The Catholic exposition and the Industrial Exhibition were both part of the effort on the part of Portuguese India to retain a dominance that was increasingly jeopardised. The Portuguese right to the Padroado - the agreement between Portugal and the Holy See in which the Pope delegated to the King of Portugal the responsibility for all Catholic religious superintendency in those places dominated by the Portuguese - was being widely questioned (another Concordata between Portugal and the Holy See had been signed in 1857). To display the most important Catholic relic in the whole of Asia through a public ceremony thus became a strategy to legitimise Portuguese Catholic sovereignty. Additionally, Portuguese India was perceived as being in decline. The point of comparison was both set in the past, with references to the Empire at its height of power centuries ago, and in the present, with allusions made to neighbouring and prosperous British India. To those in the colonising metropolis of Lisbon, Goa had become too distant in geographical terms and viewed as secondary amongst its overseas priorities, which were focused on the possibilities of an African dominion. 
The strength of the British Empire next door was quite visible by the time of the 1860 Industrial Exhibition. After the suppression of the 1857 Revolt against British rule, the governing model of the East India Company was replaced in 1858 by direct rule by the British Crown. Those discourses and practices of economic, industrial and educational development that "invented" industrial exhibitions were taking place in British India, and Portuguese India knew about them. Therefore, to organise a religious exposition by the end of 1859 , followed by an industrial exhibition by the beginning of 1860, was a way for the political, intellectual and religious elite of Portuguese India to affirm their place and their voice within a context that tended to silence them.

The 1860 Industrial Exhibition in Goa appears to be the first exhibition organised within the Portuguese colonial territories although an article published in Lisbon in 1882 - "Agricultural Exhibitions Overseas" - claims this title for one such event held in Cape Verde in 1881 (Costa, 1882). The author states that the first step in the process of holding exhibitions overseas can be found in the order signed by José da Silva Mendes Leal, then Minister of the Navy and Overseas Territories, dated 26 September 1864 (ibidem). This order was sent to all the governors-general within the Portuguese imperial space, but local initiative in India had in fact put the idea into practice almost five years earlier. Goa had anticipated the metropolitan recommendation thus revealing a remarkable autonomy, especially in the cultural, intellectual and scholarly sphere, prompted by an active group of local men. These men were Goa-born (mostly from the Catholic Brahman Indian elite or from families that had in previous centuries immigrated from Portugal and claimed the identity of "Luso-descendants"), or Portuguese-born (members of the Portuguese colonial administration). As we shall see, they were engaged in the creation of a public, local culture, in which to know Goa and to make it known was the objective of a wide array of initiatives.

An acute self-consciousness of the decline of the Portuguese Indian empire in relation to an idealised past was, in itself, a nineteenth-century local historical construct that has to be placed within a wider phenomenon of Goa's historicisation, produced locally and by locals. "Goa" became the laboratory, the place to be thought about, written about, and made known through images, objects, and words - very often, by Goans themselves. The 1860 Exhibition, as well as the other exhibitions which took place in Goa until 1952, should be placed alongside other cultural and intellectual instruments which produce knowledge about Goa and raise consciousness on Goa's past and present histories and specificities. Exhibitions could, thus, be related to: the publication of historical sources, books and journals; the making of private and public museums and cultural institutes; the legislation 
concerned with the preservation of monuments; and the encompassing photographic project of the local studio Souza and Paul. The 1860 Exhibition should also be analysed as a local attempt to appropriate contemporary discourses and practices of "modernity", "progress" and "civilisation", and thus challenge the strong perceptions of backwardness and decline which were also present and made tangible through the local thriving press.

This article, in which I will only concentrate on one case-study, is part of a larger project of researching and writing on the exhibition history and culture of Portuguese and British Colonial India and in the nineteenth and twentieth centuries. Within Goa, my project focuses on a one-century cycle which begins with the 1860 Exhibition and culminates with the 1952 Exhibition, which was also associated with the cult of St. Francis and took place at a politically charged moment: India's independence from Great Britain had taken place only a few years prior to this, in 1947. International pressure on Goa was becoming more intense, with Nehru's India challenging the obsolete character of "Portuguese India" at a historical moment in which global political forces were going in the opposing direction of decolonisation, and Goans were dealing with conflicting attitudes towards Portuguese sovereignty.

Through analysis of the 1860 Exhibition, I will first try to explore the relevance of local involvement, agency and initiative; second, the need to place exhibitions in the context of cultural, intellectual, religious and political efforts aimed at the renewal and identification of "Goa"; third, how Hindu Goa found its historical and display space next to Catholic Goa; fourth, the ways in which Goan exhibitions have to be examined within a wider, neighbouring, British India; and, finally, the ways in which exhibitions were adapted to very distinct and even opposing ideological historical and political contexts. These five lines of research are shaped by a central argument: historiographically leaving Europe and the colonising metropolis while concentrating on exhibitions that took place in colonised spaces allows us to rethink colonial experiences and relationships. If I had been searching only for Goan representations in exhibitions in Portugal or in Paris or in London, I would not have found the rich texture of Goan knowledge production, publications actually published in Goa, by Goans and Portuguese living in Goa, in addition to publications on Goa. Considered within a wider network of self-reflection, exhibitions could certainly be included in Benedict Anderson's useful "map, census, museum" trilogy, as sites for the forging of nationhood and self-identity (Anderson, 1983). ${ }^{2}$ Assembling all that could represent Goa in

\footnotetext{
2 Janaki Nair considers that the Dasara Exhibition, in Mysore, contributed to forging an idea of "nation" through the exhibition practice of staging "imagined economies" (Nair, 2013).
} 
one public space could be an exercise of empowerment, distinction and independence that challenged colonial hegemony itself.

\section{Exhibitions beyond the West: The Globalisation of Historiography}

Exhibitions are rich hybrid enterprises that can be approached through all modes of historical analysis - economic, political, artistic, visual, intellectual, cultural or industrial - and have by now a thriving historiography. Goan exhibitions emerge as rich case studies because they fit neatly into the theoretical transformations taking place in the last decade within studies of nineteenth-century universal and colonial exhibitions. In these studies, a Foucauldian perspective, which thought of colonial exhibitions as one more instrument of propaganda and power and a sign of the hegemony of the colonial government, was replaced by analyses which are much more attentive to what was occurring in those spaces that were being exhibited. This theoretical move into a more colony-centred, globalised, historiographical approach has shown, in various cases, a greater involvement of those locals who were subject to colonising governments than would have been expected (Lewis, 2013). Goa's case, with a local masculine elite actively engaged in the building of a visual and written Goa, is a particularly inspiring one.

An approach focused on global intellectual history has, in more recent years, contributed greatly to widening the map of historiographical discussion (Ganger and Lewis, 2013). Beyond Europe, in spaces that were under the control of European nations, a rich intellectual and scholarly production developed, characterised by a diversity and prolixity that cannot be understood merely through a colonial lens. ${ }^{3}$ Some case-studies have contributed to expanding the plurality of questions triggered by a more site-specific approach to colonised spaces. The analysis of exhibitions held in places other than the major European cities has enriched a historiography more attentive to the interstices of the global with the local. Such geographical diversified analysis enables us to attest to how exhibitions were also held in places other than London or Paris, such as Goa, which could not fully claim those values of development, modernity and commodity culture as defined by Arjun Appadurai (1986) but which nevertheless desired to participate in the same paradigms. To organise an "industrial exhibition" in Goa as early as 1860 despite having hardly any industry was an example of the globalisation of this model and this language.

\footnotetext{
3 Some works are not especifically concentrated on exhibitions but are however, crucial to understand the wider museum, monument and historical valuing of Indian material culture. See for example: Tapati Guha-Thakurta, 2004; Maria Antonella Pelizzari, 2003.
} 
It is pertinent, therefore, to move beyond the metropolitan colonial itinerary away from the Lisbon-Goa paths of political communication and correspondence and concentrate on other spatial frames, both a global one and an Asian one, in which Goa is thought of in relation to a wider India. ${ }^{4}$ Goa's particularly rich case, however, has not been acknowledged in the recent bibliography on exhibitions outside Europe and the United States, which is more concentrated on British colonial Asia and on South America, and is particularly attentive to interchanges within different colonial spaces within the British empire. ${ }^{5}$ Likewise, the historiography of nineteenth- and twentieth-century Portuguese colonial India has not included the treatment of exhibitions. Histories of the economic or industrial history of Goa that also comprise the nineteenth century have not used exhibitions as sources (Souza, 1990). ${ }^{6}$ While histories of art, architecture and design tend to concentrate on an earlier period and therefore also miss the exhibition's potential as objects of research. ${ }^{7}$ In addition, essays on Goan scholars which examine their biographies do not mention their involvement in exhibitions. "Exposição", when studied in the Goan context, tends to refer to the religious "Exposição" of St. Francis' miraculously preserved body. The most obvious explanation is that the rich historiography of Goa has favoured the early modern period while the reflections on a more recent period have been much more fragmented.

As always happens, temporary exhibitions leave permanent written traces. In Goa's case, however, some are easier to find than others. The local press, which was created in the sixteenth century and which, after a long hiatus, was reactivated in the nineteenth century (Xavier, 1876), prompted a very rich local print culture which Rochelle Pinto wonderfully revealed in her book Print and Politics in Goa (Pinto, 2007) and which Sandra Lobo has explored in her central thesis in Culture and Politics in Goa from Liberalism to the Colonial Act (Lobo, 2013). Many of these are not easily available in libraries and tend to be scattered and fragmented throughout the contemporary press or the Official Governmental Bulletin.

\section{Exhibitions in India: Placing Goa in a Wider Context}

What was the worldwide context of exhibitions during the transition from the 1850 s to the 1860 s, when Goa held its first exhibition? London in 1851,

\footnotetext{
${ }^{4}$ A claim for wider historiographical frames, beyond the axis metropolis-colony, has been made by many among which Durba Ghosh and Dane Kennedy (2006).

${ }^{5}$ For example, the relationships between exhibitions in Australia and India (McKeich, 2011).

${ }^{6}$ A small article published in Goa in 1910 should, however, be noted: "Exposições industriaes em Goa”, O Oriente Português, 1-2 (January-February), pp. 60-62.

${ }^{7}$ For example, Percival de Noronha (2000) concentrates on previous centuries and not in the ways in which Indo-Portuguese objects were displayed at Goan nineteenth-century exhibitions.
} 
with the Great Exhibition of All Nations, was followed by Paris in 1855, London again in 1862, and then again Paris, five years later in $1867 .{ }^{8}$ Only in the 1870s did this model of exhibition - temporary, comprehensive and international - transfer from Europe to other geographies and spaces. However, already in the 1860s there were multiple local initiatives throughout the world, much less ambitious in scope, but which nevertheless already revealed the global impact of the model of all-encompassing exhibitions of a national or regional character, ones which represented a region that could also be a colonised territory, such as Goa.

The bibliography of exhibitions related to India has, thus, tended to focus on two different areas of interest: representations of India at European exhibitions, about which Carol Breckenridge's article was pioneer (1989), and exhibitions held in British India where, even when "India" is referred to as a whole, Goa is not included in the analysis (even when it was one of the official participants) (Nair, 2013; Tillotson, 2004). Another, more recent and geographically wider historiographical field would be that which concentrates on exhibitions outside Europe and the United States (Chaudhuri, 2018; Kal, 2005). Peter Hoffenberg's book (2001) analyses many such events in India, New Zealand, and Australia, different spaces under British political dominion, as well as the relationships between them. Hoffenberg, like McKeich, highlights the involvement of Indian men in the making of exhibitions in India and in India representations abroad, a circumstance we can also see in Goa, with the active agency of Goan men in negotiating and deciding what should represent Goa, at home and abroad (McKeich, 2011).

Since the 1850s, following the Great Exhibition of 1851 in London, notice had been taken of exhibitions, mainly agricultural, organised in many British Indian cities. As Gyan Prakash (1992) stated, exhibitions were a "feast for the Indian eye", with its multiple ways of attracting visitors. They fit well into the Hindu Mela tradition of holding commodities and animals fairs, sometimes associated with religious events. The first international Indian exhibition, with one million visitors, is considered to be the event held in Calcutta in 1883-1884. ${ }^{9}$ In another British colony, New Zealand, the word "international" had already been used in $1865 .{ }^{10}$ Prior to the Calcutta

\footnotetext{
${ }^{8}$ Relatório acompanhado da relação dos objectos enviados à Comissão Central de Lisboa directora dos trabalhos preparatórios para a Exposição Universal de 1867 em Paris pela Comissão do Estado da Índia Portuguesa (1866). Nova Goa: Imprensa Nacional.

${ }^{9}$ Official Report of the Calcutta International Exbibition. 1883-84: Compiled under the orders of the Executive Committee, vol. I-II (1885). Calcutta: Bengal Secretariat Press. See also: Powell, 1990; Hoffenberg, 2003; Guha-Thakurta, 2004.

${ }^{10}$ In New Zealand two major international exhibitions were organised, in 1865 and in 1889 (Rice, 2015: 231-250).
} 
International Exhibition of 1883, there had already been a few exhibitions in India - the one in Goa in 1860 and a few others in British India (Nagpore Exhibition, 1865) - which had not used the word "international" but had made a conscious effort to include products from outside their strict borders, often from other parts of India or within the British empire.

The Madras Exhibition (now Chennai, on the Bay of Bengal in eastern India), which took place in 1859 - and where Goa also participated along with "Mysore, Hyderabad, Nagpore, Travancore, Cochim, Pondichery", the French colony, as well as "Ceylon, Pegú, Malaca, Indian archipelago and the Provinces of Tenasserim" - was clearly an influence for the Goa 1860 Exhibition. The official governmental Bulletin gives extensive coverage of its organisation and of the Goan participation, by publishing the instructions for exhibitors and the classes where they could place their products. ${ }^{11}$ By December 1859, the same Bulletin (Boletim do Governo do Estado da Índia from now on Boletim do Governo) lists the products that were sent from Goa to Madras, as had appeared in the printed Catálogo classificado das matérias primas apresentadas na Exposição de Madrasta em 1859, publicado por autoridade superior. ${ }^{12}$ As we shall see, this idea of displaying a wider India, and even a wider Asia, and thus promoting a commercial relationship within geographies that went beyond national or colonial frontiers, would also be present in the aims of the 1860 Goa Exhibition.

\section{An Industrial Exhibition in 1860: Goa's Response to the Challenges of Modernity}

The Industrial Exhibition of Portuguese India opened at the Palácio Archiepiscopal de Goa [Archbishop's Palace], on the $12^{\text {th }}$ of January, shortly after the closing of St. Francis Xavier rituals that had taken place in the same city, Old Goa [Velha Goa], the former capital of the Portuguese Empire of India, and remained opened until the $8^{\text {th }}$ of February: "The religious Exhibition was followed by the Industrial one, in which apart from those products of nature and of art from the Portuguese territories, but also many products from a variety of Indian regions". 13

The intent to organise an industrial exhibition following the religious one was announced in the official governmental publication in the previous summer. ${ }^{14}$

\footnotetext{
${ }_{11}$ Boletim do Governo (1858), no. 67, 27 August, pp. 497, 498.

${ }_{12}$ Boletim do Governo (1859), no. 99, 20 December, pp. 649, 650.

13 "Discurso de S. Ex. a o Sr. Governador Geral, na Sessão da abertura da Junta Geral de Distrito, em 11 de Novembro de 1860", Boletim do Governo (1860), no. 90, 16 November, p. 700; See also "Nova Goa, 12 de Janeiro de 1860", Boletim do Governo (1860), no. 4, 13 January, p. 20.

14 "Notas que devem servir de base ao Plano para a Exposição que se pretende abrir na Capital da Cidade de Nova-Goa" [from now on mentioned as "Notas que devem servir de base ao Plano para a Exposição"], Boletim do Governo (1859), no. 43, 7 June, pp. 269-270.
} 
Even if the first proposal arose in 1857 from the Junta Geral do Distrito and became a decree on the $28^{\text {th }}$ of May $1859 .{ }^{15}$ Nothing suggests that Lisbon was involved, although the event was officially sponsored by the local Portuguese government via the Visconde de Torres Novas, the Governor-General. ${ }^{16}$ At an early stage the intention was to build a "pavillion" in the capital city of Nova Goa, with all the necessary conditions to host the exhibition. However, this plan never went ahead and finally an already existing building, not in Nova Goa, but in the former capital of Velha Goa was adapted for that purpose. Therefore, even if the initial idea seems to have been to construct a new, temporary building in the capital, in the end, a more economical option seems to have been chosen. The exhibition was staged in an unused religious space, one of many that had been stripped of their previous function and significance after the eighteenth-century abandonment of the capital, the expulsion of the Jesuits by the Marquês de Pombal and the 1834 nationalisation of the property held by the male monastic orders.

Using statistics as a tool for measurement and a source of knowledge, the Statistical Report of 1862 on all Portuguese Colonies, commissioned by the King of Portugal, summarised what was being done in Portugal's colonies in Africa and India (Lima and Bordalo, 1862). The 1860 Industrial Exhibition is referred to, along with other examples of progress and public improvements that had recently taken place in Goa - from the restoration of the seventeenth-century "Ribandar Bridge" to the introduction of the electric telegraph and the public display of the saintly remains of St. Francis Xavier (ibidem: 40). In the laudatory words written to the Governor-General in the Exhibition catalogue, the organising commission placed the "contest of the national industry of the country" as part of the "long road of material improvements which in civilised Europe were in such rapid progress". ${ }^{17}$ The 1860 Goan Industrial Exhibition was presented mainly as a diagnostic tool, a way to better understand the territory's own industrial and agricultural resources while putting it on the paths of progress that were being established by some European nations and were already visible in neighbouring British India. ${ }^{18}$

\footnotetext{
15 The Junta Geral was a Portuguese administrative body in charge of public instruction, industrial and agricultural development, and public works. Created in 1832, it existed until 1936. See "Exposições industriaes em Goa", O Oriente Português, 1-2 (January-February 1910), p. 60.

${ }_{16}$ António César de Vasconcelos Correia, Visconde (and then Conde) de Torres Novas, was governor from 3 November 1855 to 24 December 1864.

${ }_{17}$ Relatório e catálogo da Exposição Industrial, 1860, p. iii.

18 "Discurso de S. Ex. a o Sr. Governador Geral, na sessão da abertura da Junta Geral de Distrito, em 7 de Novembro de 1859", Boletim do Governo (1859), no. 87, pp. 571-572.
} 
Holding an industrial exhibition was seen as the thermometer by which one could gauge and promote the industry and wealth of a country. According to the evaluation of the Junta, the first event to take place in Portuguese India on such a scale exceeded the expectations of both the public and foreign visitors because it gave the idea that the country had dimensions and elements which, if well explored, could be of public utility. ${ }^{19}$ The Exhibition sparked local interest in studying the region's agriculture and all the natural products that could contribute to the region's economic development. There was a global language of commercial development around the making of these events, even if the context of Goan exhibitions had nothing to do with the consumer culture that could be seen in cities such as London or Paris. This was not contradictory to the aim of featuring items that were only on display but not for sale and which belonged to a culture of collection rather than commerce. The 1860 Goa Exhibition, like so many other exhibitions in this period, appropriated different kinds of paradigms of display and classification, which shows the flexibility of exhibition spaces in adjusting to a multiplicity of aims, interests, discourses and agents. It combined the idiosyncratic choices of individuals with the scholarly domains of knowledge that were taking shape in the nineteenth century, such as ethnography. It combined the personal collections of those who, not by chance, were also involved in their creation, with contemporary ways of thinking about a territorial space.

\section{Who Organised the Exhibitions? The Local Agency of a Global Model}

Identifying the names of the men who belonged to the organising commission allows us to understand the social and ethnic composition of the male elite whose names appear in so many other cultural and intellectual Goan initiatives of this period. In other colonial spaces, this would be an easier exercise. In an exhibition in British India, for example, the names themselves would be sufficient to distinguish those who were white British men from those who were Indian men, most probably Hindu, but also Muslim (McKeich, 2011: 104-123). In the case of nineteenth-century Goa, however, many in the Indian population had been converted to Catholicism in previous generations, and adopting a "Portuguese" or "Christian" name was part of the process of conversion. Therefore, one has to go beyond the names and delve into other biographical material in order to better understand who the members of the exhibition committees were. They were not only the local Portuguese administrative authorities, but also Goans

19 “Junta Geral do Distrito", Boletim do Governo (1860), no. 93, 27 November, p. 723. 
belonging to the local elite, some of them Catholic and ethnically Indian, of the Brahmin caste. ${ }^{20}$

The members of the 1860 Exhibition Commission were: Visconde de Torres Novas, the Portuguese Governor-General; Joaquim Heliodoro da Cunha Rivara, Joaquim Manuel de Mello e Mendonça, José António de Oliveira, ${ }^{21}$ João Ferreira Pinto and José Manuel de Carvalho e Sousa, all from Portugal, the colonising power and Candido José Mourão Garcez Palha, ${ }^{22}$ Vitor Anastacio Mourão Garcez Palha, Bernardo Francisco da Costa and Filipe Neri Xavier, these last four born in Goa, and Catholic, the first two "Luso-descendants". ${ }^{23}$ This was a problematic category for those Goans who considered themselves descendants of the "first" Portuguese colonisers - the Portuguese present at the time of the sixteenth-century conquest of India and therefore distinguished themselves from those Catholic Goans who were descendants of converted Hindus, and therefore ethnically Indian, as was the case of Filipe Neri Xavier.

Filipe Neri Xavier (Loutolim, 1801 - Pangim, 1875) deserves a whole biography and a few short lines will do no justice to the role he played in so many aspects of Goan literary, scholarly, historical, archaeological, administrative and political life. Professionally, he was the head of the National Press in Goa as well as occupying an administrative position working for the Government's Secretary General, a very important political position which was always occupied by a man nominated by Lisbon. The fact that he worked for Joaquim Heliodoro da Cunha Rivara, a historian who held the seat of Secretary General for twenty-two years, may help to explain how Neri Xavier could develop his wide intellectual interests while in Rivara's employ. ${ }^{24}$ This being so, as Teótonio de Souza (1981: 116) has noted, his being Goan within a Portuguese administration might have limited the

20 "Acta da Comissão Central da Exposição", Boletim do Governo (1859), no. 48, 25 June, p. 309.

${ }^{21}$ José António de Oliveira (Marinha Grande, 1817 - Nova Goa, 1872). I thank Cristiana Bastos for passing me the biographical portrait she had compiled on him. On colonial medicine in Goa during the $19^{\text {th }}$ century see, for example, Bastos, 2007: 767-782.

22 Cândido José Mourão Garcez Palha (Ribandar, Goa, 1810-1873) by the time of the exhibition was already given the aristocratic title of Visconde de Bucelas, and other prestigious commendations, no doubt a sign of recognition on the part of the Portuguese colonial authorities for his public service. A military engineer, head of the Military Court Commission, Director of the Military Archive and of Telegraphs, and Inspector of Public works, amongst other professional roles, he also manifested his literary and professional ambitions through the publication of a wide array of texts, from sonnets to the Portuguese king to reports on various fields of knowledge, from drawing to meteorology (Costa, 1997, vol. II: 21-23).

${ }_{23}$ For bibliographical entries on these men, see Costa (1997) and Pope (1989 [1937]).

${ }^{24}$ In 1874, the Goan Miguel Vicente de Abreu already analysed the relationship between Cunha Rivara and Neri Xavier: see Abreu, 1874; Costa, 1997, vol. III: 348-356. 
kind of reading and interpretation he could pursue with the sixteenth- and seventeenth-century sources he published (ibidem: 114-131).

These were some of the figures who would also participate in other committees involved in assembling the Goan material and visual displays, in Goa or abroad, during the second half of the nineteenth century. The Portuguese citizen, Cunha Rivara, for example, who wrote on an extremely diverse array of issues related to the past and present of Goa, translated an article into Portuguese on the Exhibition of Madras which took place in 1859, shortly before the first Goan Exhibition..$^{25}$ These were also the personages who were participating in the definition of Goa's past and present through their writing on its history, writing in newspapers, and being involved in the creation of local cultural institutions.

\section{Ways of Displaying Goa: Objects and Classifications}

On the opening day, the Governor-General spent two hours "attentively examining each object" and left "pleased with the good order and the variety of natural and artificial products that could be found at the exhibition" ${ }^{26}$ Paid admission tickets were needed to see the eight rooms of the exhibition (although for three days no admission was charged) while two musical bands were always entertaining the visitors. ${ }^{27}$ On the day after the closing of the exhibition, the Boletim do Governo announced that the catalogue would be "published as soon as possible, satisfying public expectations and providing material for a calmer appreciation than was possible in a rapid visit to the Exhibition rooms". ${ }^{28}$ The catalogue, even if not ready at the time of the opening, is itself proof of the investment put into the exhibition. There were a few examples of industrial machinery - if only to justify the ambitious title of "Industrial Exhibition" - but these symbols of the modernity which the exhibition sought to promote were not numerous enough to balance the overwhelming predominance of agricultural products - from medicinal plants to staple foods - and different kinds of hand-made objects either for domestic or religious use or of an ornamental character. Beyond the world of commodities, the exhibition calling had already encouraged artisans to send their hand-made artefacts, "Portuguese hands" or "foreign hands", both living in Goa or "in foreign territories" as well as any work of "Poetry, Music and Painting". 29

\footnotetext{
25 “Exposição de Madrasta para o ano de 1859", Boletim do Governo (1858), no. 67, 27 August, pp. 497-498; no. 68, 31 August, pp. 506-507.

26 “Nova Goa, 12 de janeiro de 1860", Boletim do Governo (1860), no. 4, 13 January, p. 20

${ }^{27}$ See Relatório e catálogo da Exposição Industrial, 1860, p. iv; and "Notas que devem servir de base ao Plano para a Exposição", Boletim do Governo (1859), no. 43, 7 June, p. 270.

28 "Nova-Goa, 9 de fevereiro de 1860", Boletim do Governo (1860), no. 12, 10 February, p. 80.

29 "Notas que devem servir de base ao Plano para a Exposição", Boletim do Governo (1859), no. 43, 7 June, pp. 269-270.
} 
Two of the exhibition's 99 sections were revelatory: one was named "Customs of the Country" and exhibited a "collection of uses and customs of Goa" contributed by Neri Xavier, a collector and also a member of the commission, while another was named "Asian Customs" and included almost two hundred wooden figures. Another catalogue entry mentioned "Various gentile figures", meaning representations of Hindu gods made from a range of materials. An adjoining section had an ivory crucifix and a figure of Our Lady of Pity, with some objects on display being directly associated with the contemporary exhibition of the body of St. Francis Xavier, as they portrayed the saint's life or image. Among the "Ivory miniatures", 82 kings of Persia shared a space with a "miniature portrait of a lady" sent by Garcez Palha, another of the exhibition organisers who was also a collector. There was a clear tendency to exhibit anything that could be identified with "Goa" - anything which was locally made and could somehow contribute to distinguishing the territory from other places. These items ranged from local coins to Catholic images and drawings of local churches, convents and forts, Goan sights, which had also been identified through historical and travel writing and travel guides. ${ }^{30}$

Both Neri Xavier and Garcez Palha, widely published Goan authors and both members of the organising committee, took advantage of the opportunity to publicly display their private collection at the Archbishop's Palace. ${ }^{31}$ The former lent his collection of stamps and arms from "the ancient chiefs of Hindustan" and some "early gentile kings of Goa", gentile here meaning non-Christian, and therefore Hindu or Muslim, while Garcez Palha exhibited his collection of stamps from Goa's Casa da Misericórdia. Arms and musical instruments used by the people, a glass "from the time of King João v", some coins with "gentile dies" and "effigies of their gods" were also exhibited, alongside other objects from the Malabar Coast that had been found in an excavation in Goa.

By the middle of the nineteenth century, there was already a display space in a Catholic archbishop's palace for artefacts of Hindu material culture, which in previous centuries had been violently destroyed. Within the context of the sixteenth- and seventeenth-century forced conversion of Hindus to Catholicism, these artefacts had been considered heathen symbols and were symbolically erased and replaced by the prolific material culture of Goan Catholicism, later classified as "Indo-Portuguese art" (Vicente, 2003: 37-55). In this period, however, when forced conversion was no longer the aim of the colonial government, even if investment in Catholic hegemony still

${ }^{30}$ Relatório e catálogo da Exposição Industrial, 1860, pp. 6, 8, 83-87.

${ }^{31}$ Relatório e catálogo da Exposição Industrial, 1860. 
was, Hindu material culture was no longer a threat. ${ }^{32}$ The fact that so many Hindu objects were on display was indicative of the new type of knowledge of the "country" that was beginning to emerge; a culture that had been previously suppressed was now put into a space of public visibility, next to other objects, products, symbols, and examples of a "local" material culture. In an encompassing visual narrative of Goa's past and present, Hindu Goa by the mid-nineteenth century could be exhibited next to Catholic Goa.

Both the number and the nature of the female exhibitors merit note. They were simultaneously exhibitors and producers, mainly of those hand-produced textiles that could be created within the confines of individual homes. The prominence of female exhibitors in Goa is analogous to the widespread participation of women as exhibitors in contemporary European universal exhibitions (Vicente, 2017: 315-345). Women do not appear yet as collectors or as authors, in Europe or in Asia, but they were a major presence as exhibitors of that which can be produced domestically with their hands, and commercialised locally, such as all kinds of "Embroideries" ["Bordados"], pieces of clothing, other small handicrafts, and preserves. ${ }^{33}$ In Goa, the 21 women exhibitors were all given an honourable mention, an apparently condescending strategy to value their participation without evaluating them within the competition distinguished by gold and silver medals and by third class prizes. The jury commission - constituted of 17 men from different parts of $\mathrm{Goa}^{34}$ - attributed the prizes within a ceremony that took place on the $24^{\text {th }}$ of May. ${ }^{35}$ Amongst the six gold medal winners, there were three factories and three individuals: a gunpowder factory, a sugar factory and another one producing spirits and liqueurs whereas the three artisans, all with Hindu names, were carpenters and goldsmiths.

We have no knowledge of the existence of any image - drawing, print or photograph - of the actual exhibition. ${ }^{36}$ However, through the descriptions in the printed catalogue, we know that "photography" appeared as no. 21 of the 99 "classes" (between the entry on "oil canvases" and that on "lithography"). ${ }^{37}$ Finally, only two photographs seem to have been on display, along with

\footnotetext{
32 On Hindu Goa, see Rosa Maria Perez (2011) and Robert S. Newman, (2001).

${ }^{33}$ Relatório e catálogo da Exposição Industrial, 1860, pp. 13-23.

34 "Exposição Industrial. Relação dos individuos, de que deve compor-se o Corpo de Jurados [...]", Boletim Oficial (1860), no. 11, 7 February, pp. 72-73.

35 "Exposição de Industria na Índia Portuguesa sendo Governador Geral o Exmo. Visconde de Torres Novas 1860. Notas das pessoas que receberam prémios e menções honrosas [...]”, Boletim do Governo (1860), no. 42, 1 June, pp. 305-306.

36 The Exhibition of 1890 , on the contrary, was widely photographed by the Photographic Studio Souza and Paul (Vicente, 2014: 319-342).

${ }^{37}$ Relatório e catálogo da Exposição Industrial, 1860, pp. v, 10, 93.
} 
references to the men who had sent them: a "book with photographic plates" from Hormesgy Cangy Bengaly and a "portrait in glass" by Thomaz de Aquino Mourão, the son of Garcez Palha who contributed extensively to the exhibition through the loan of personal items. ${ }^{38}$ No photography won a prize but three sets of drawings received an honourable mention, the consolation prize that was also given to the ladies - drawings by José Federico de Assa Castel-Branco, those signed by the best students of the Mathematics and Military School and the cartographical materials from the Military Archive. ${ }^{39}$

\section{"Foreign Goods": Indian Involvement in the Goa Exhibition}

The 1862 Statistical Report on all "Portuguese possessions" underscored how the 1860 Exhibition did not limit itself to products from Portuguese India, but also included samples from "all of Hindustan", therefore locating the small territories of the Portuguese colony within a wider India and somehow transcending the national (Portuguese) and regional (Goan) scope of the exhibition (Lima and Bordalo, 1862). The example of the Madras exhibition in the previous year, also including other parts of India, must have been an influence. To achieve this goal, a Bombay Commission was charged with collecting the most representative "samples of economic and industrial products" from the Bombay Presidency. ${ }^{40}$ The Central Museum of Bombay along with private individuals also contributed to put together "this collection".

Usually exhibitions used the words "international", "universal" or "world", and later "colonial", to state their global scope and distinguish themselves from those exhibitions that were only national in scope. However, through the case of Indian nineteenth-century exhibitions, we can see how this division does not apply. In the case of Madras, in 1859, or Goa, in 1860, there was an effort to involve neighbouring regions which, as we have seen, belonged to other imperial, and therefore, national, contexts. Bombay's privileged relationship with Goa can be explained by its geographical proximity, its former relationship with Portuguese territorial and religious hegemony, and to the fact that it had a thriving Goan immigrant community with established

\footnotetext{
${ }^{38}$ I could not identify the Parsi man, but only Tomás de Aquino Mourão Garcez Palha (1842-1904), son of Cândido José. A very young man at the time of the exhibition, soon afterwards, in 1863, he occupied an official position as the head of the Trading Post of Surate, then becoming a Member of Parliament. As the head of primary instruction, he became very involved in the teaching and the promotion of both Maratha and Konkani. In relation to Konkani, his interest had both a contemporary strand, in teaching, and a historical one, in his willingness to re-publish rare works written in the language (Costa, 1997, Dicionário de Literatura Goesa, vol. II, pp. 24-29).

39 “Exposição de Industria na Índia Portuguesa [...]”, Boletim do Governo (1860), no. 42, 1 June, pp. 305-306.

40 "Exposição Industrial", Boletim do Governo (1860), no. 1, 3 January, p. 5.
} 
links to Goa. This explains why Bombay had a Comissão Filial in charge of organising its display, equivalent to that of other Portuguese India territories such as the New Conquests, those Goan territories, which only came under Portuguese domination in the eighteenth century (as opposed to the Old Conquests, territories held since the sixteenth century). ${ }^{41}$

In 1859, a few months before the announced opening, John Craig, editor of the Bombay Standard wrote to the Goan organising Commission expressing his total support of the Exhibition and offering to publish any information issued by them. ${ }^{42} \mathrm{He}$ also sent to Goa the article that had been published in the Bombay Standard a few weeks previous, to encourage Bombay's participation in the upcoming exhibition. With clear irony, the article revealed how Bombay was "offended" when the news of the Goan exhibition arrived from Calcutta instead of directly from Portuguese India: "we certainly have mail between Bombay and Goa" and, concluded the article, "we solicit not to be made dependent from Calcutta, in relation to future news of Goa". ${ }^{43}$

Other non-Goan participants appeared as individual exhibitors. Hormesgy Cangy Bangaly, a Parsi resident in Bombay, for example, participated as the maker of "a pair of sandalwood chairs with ivory marquetry", which became the most talked-about piece at the exhibition. ${ }^{44} \mathrm{He}$ was awarded a gold medal, a distinction only granted to two other craftsmen, and later saw his work taken to Lisbon as a gift for the King of Portugal, after the Junta of the Exchequer of the State of India decided to purchase the chairs for 1,500 rupees. ${ }^{45}$ The gift had two aims: first, to give King Pedro V two "objects from India", the "perfection" of which made them worthy of being placed at the royal palace alongside other fine pieces ${ }^{46}$ and, second, to encourage "future exhibitions" and publicise the Goan Exhibition in Lisbon, the capital of the empire. Although this Exhibition had been the first "to have been held in our Indian possessions, it had many objects whose perfection attracted the attention of both the Portuguese and the foreigners who visited the exhibition". ${ }^{47}$

\footnotetext{
41 "Notas que devem servir de base ao Plano para a Exposição", Boletim do Governo (1859), no. 43, 7 June, pp. 269-270.

42 “Comissão Central da Exposição Industrial”, Boletim do Governo (1859), no. 95, 6 December, p. 624.

43 "Artigo do Bombay Standard de 22 de outubro de 1859", Boletim do Governo (1859), no. 95, 6 December, pp. 624-625; on how the preparatives were being accompanied by the newspaper Bombay Catholic Examiner see: "Exposição Industrial", Boletim do Governo (1860), no. 1, 3 January, p. 9.

${ }^{44}$ Relatório e catálogo da Exposição Industrial, 1860, p. 30.

${ }^{45}$ Relatório e catálogo da Exposição Industrial, 1860, p. 89.

${ }^{46}$ AHU/DGU/India/Pasta 25-1860/1861 (7/125/5). Order to the government of the State of India from the Junta of the Exchequer of the State of India, 15 May 1860.

47 AHU/DGU/India/Pasta 25-1860/1861 (7/125/5). Paper 7 from 1860 - Copy of a part of the minutes from the meeting of the Junta of the Exchequer, 29 May 1860.
} 
Shortly before the opening, some illustrious visitors from Bombay - "politicians and erudites" - were expected to go to Goa just to visit the Exhibition: its governor, Lord Elphinstone; Dr. Henry John Carter, a surgeon who worked as a geologist and zoologist; Dr. Bhau Daji Lad, the Indian physician, Sanskrit scholar and antiquary, who had been born in Goa before moving to Bombay; some illustrious members of the Parsi community, Manockjee Cursetjee, a businessman and judge from Bombay, known for being a reformer and promoter of female education and Kharshedji Rustomji Cama, a Parsi scholar and political reformer; and George Birdwood, the only visitor on whom we could actually find references to. ${ }^{48}$

Birdwood, one of the main contributors to the definition of both what Indian art was and what it should not be, visited the Goa Exhibition but, as far as we know, did not write about it. As the curator of London's India Museum, the curator of the Bombay Victoria and Albert Museum [Bhau Daji Lad Museum, since 1975] (MacKenzie, 2009: 239), and the organiser of the British India section at the Paris Exposition Universelle in 1878, in different moments of his life, Birdwood was one of the great theorists of the need to preserve and renew the artisanal qualities of Indian crafts. He actively participated in the definition of an Indian material and visual identity both in India itself and outside of India - in London, the metropolitan capital of the empire, and in Paris, the main nineteenth-century global site for the display of national artistic identities through universal exhibitions. ${ }^{49}$

Birdwood published widely on Indian material culture and his book Industrial Arts of India became an established reference (Birdwood, 1880). When later he wrote on the "Invention of the Indies" in his Report on the Old Records of the India Office, an ode to the historical relevance of Indian trade for European history, his knowledge about the materiality of things went beyond those objects considered "arts and crafts" to include everything that was "natural", a testimony to his earlier medical career (ibidem, 1891). It was within this line of research that he included three references to Goa's products in the famous 1903 dictionary Hobson-Jobson - a glossary of colloquial Anglo-Indian words and phrases (ibidem, 1968 [1903]: 379).

\section{Conclusion: Exhibitions as Spaces for the Definition of National Identities} Apart from being instruments of colonial affirmation and legitimisation, exhibitions in Goa, as in other colonial spaces, could also be sites for the

48 "Exposição Industrial", Boletim do Governo (1860), no. 1, 3 January, p. 5.

${ }^{49}$ I analyse the India display at the 1878 Paris Exposition Universelle and at the 1886 London Colonial and Indian Exhibition in my book: Vicente, 2012: 291-301. 
agency and collaboration of different local elites, as well as for the building of a national or proto-national consciousness. Exhibitions in Goa became a laboratory for self-reflection, self-definition, and self-identification, a way of valuing their own local specificities and differences in relation to other places. And to the "other" India. When the catalogue for the Goan 1860 Industrial Exhibition includes a section on the "Collection of habits and customs from Goa", which was part of a wider section on "The Customs of the Country", isn't a national or territorial consciousness being rehearsed?

Within a recent historiographical framework in which global circulation and networking have been the subject of so many remarkable works, this article has also endeavoured to highlight the opposite phenomenon: the locality of experience - the ways in which, beyond the wider trans-colonial, transnational, or globalised movements, these were events within a circumscribed space, such as local exhibitions organised by local inhabitants, which presented local artefacts to local visitors. Even if an underlying idea was that of putting Goa on the trade map of commercial networks - identifying the local production that could be a source of export and development - it was the "local", what was Goan, in all possible material forms, which was indeed at stake.

What represented "Goa", what was put on display, and what was valued and written about was not homogeneous. Goa's material and commodity culture could mean many different things, some of them even apparently contradictory, as was the case when artefacts pertaining to Catholic ritual were exhibited next to those objects related to Hinduism. By the second half of the nineteenth century and the first decades of the twentieth, the production of historical, archaeological and linguistic knowledge about Goa also included an interest in a pre-Portuguese Goa and in a Goa that remained "Indian" despite the Portuguese presence. No longer a threat, Hinduism could become part of the scholarly scope of a non-religious Orientalism, this being an Orientalism that is no longer associated with the need to learn Indian languages as an instrument of conversion to Catholicism (Xavier and Županov, 2014). Even in Goa.

Did Portugal's distancing itself from its "Asian empire" at the time when Africa was at the centre of its colonising ambitions allow local voices, agencies and ambitions to become more freely manifest? Did the perception that Portuguese India was in a historical phase of decline after the previous centuries of achievements foster the space for a local historical and national consciousness to emerge? The Industrial Exhibition of 1860, the first of a series of exhibitions which took place in Goa for almost one hundred years, should be placed in a wider context, in which identities were being stated and in which historical pasts, contemporary presents, and envisaged futures, even 
when conflicting and contradictory, were also being actively defined. "Goa" was being defined through writing and publishing, through photographing, through excavating, through collecting, and through putting together temporary exhibitions in which all of these instruments and practices of knowledge were congregated, in a single space and in a short period of time.

An exhibition's capacity to adapt to all manners of ideological practices and discourses is certainly a global phenomenon that has been widely studied in recent decades. In 1927 British India, Gandhi was promoting exhibitions of swadeshi [indigenous goods] as part of a wider movement of Indian empowerment, which, ultimately, led to independence (Trivedi, 2003: 11-41). Meanwhile, a few years later in 1931, Paris was hosting the largest ever exhibition with the word "colonial" in its title. In Goa, exhibitions, and the political, symbolical and pragmatic value attributed to them, were not affected by the transition from the Monarchy to the Republic which took place in 1910, nor by the transition from a democratic secular Republic to a right-wing dictatorship allied with the Catholic Church, around 1930, still the context of the last major Goan exhibition, in 1952.

Exhibitions had the capacity to adapt to different political circumstances and changes. The justification for their organisation might change, but the overall idea behind the exhibition remained that of presenting the most comprehensive picture possible of the Goan territory and of encompassing the widest knowledge on Goa while promoting local commerce, agriculture, and industry as well as arts and crafts. Ultimately, what was at stake through the exhibition apparatus was also the empowering quest for self-knowledge, the act of gazing - as if in a mirror - at oneself, even when the reflection was kaleidoscopic.

Edited by Scott M. Culp

\section{References}

Abreu, Miguel Vicente de (1874), Noção de alguns filhos distintos da India portuguesa que se ilustram fora da pátria. Nova Goa: Imprensa Nacional, pp. 65-66, 161-173. Anderson, Benedict (1983), Imagined Communities: Reflections on the Origin and Spread of Nationalism. New York. Verso.

Appadurai, Arjun (ed.) (1986), The Social Life of Things: Commodities in Cultural Perspective. New York: Cambridge University Press.

Bastos, Cristiana (2007), "Medical Hybridisms and Social Boundaries: Aspects of Portuguese Colonialism in Africa and India in the Nineteenth Century", Journal of Southern African Studies, 33(4), 767-782. 
Birdwood, George (1880), The Industrial Arts of India. London: Chapman and Hall. Birdwood, George (1891), Report on the Old Records of the India Office. London: W.H. Allen.

Birdwood, George (1968), "Goa Plum”, "Goa Potato", "Goa Powder”, in Henry Yule; Arthur Coke Burnell, Hobson-Jobson, a Glossary of Colloquial Anglo-Indian Words and Phrases, and of Kindred Terms, Etymological, Historical, Geographical and Discursive. Delhi: Munshiram Manoharlal [orig. ed.: 1903].

Breckenridge, Carol (1989), "The Aesthetics and Politics of Colonial Collecting: India at World Fairs", Comparative Studies in Society and History, 3, 195-216.

Chaudhuri, Supriya (2018), "Exhibiting India: Colonial Subjects, Imperial Objects, and the Lives of Commodities", in Supriya Chaudhuri; Josephine McDonagh; Brian Murray; Rajeswari Sunder Rajan (eds.), Commodities and Culture in the Colonial World. London: Routledge, 58-73.

Costa, Aleixo Manuel da (1997), Dicionário de Literatura Goesa, vol. I-III. Lisboa: Instituto Cultural de Macau e Fundação Oriente.

Costa, Joaquim Vieira Botelho da (1882), “As exposições agrícolas no ultramar”, Boletim da Sociedade de Geografia, no. 10, $3^{\text {rd }}$ series, pp. 629-640.

Ganger, Stefanie; Lewis, Su Lin (2013), "Forum: A World of Ideas: New Pathways in Global Intellectual History c. 1880-1930”, Modern Intellectual History, 10(2), 347-351.

Ghosh, Durba; Kennedy, Dane (eds.) (2006), Decentering Empire: Britain, India and the Transcolonial World. London/Hyderabad: Sangam.

Guha-Thakurta, Tapati (2004), Monuments, Objects, Histories: Institutions of Art in Colonial and Post-colonial India. New York: Columbia University Press.

Gupta, Pamila (2014), The Relic State. St. Francis Xavier and the Politics of Ritual in Portuguese India (Manchester/New York: Manchester University Press; Palgrave Macmillan.

Hoffenberg, Peter H. (2001), An Empire on Display: English, Indian, and Australian Exhibitions from the Crystal Palace to the Great War. Berkeley, CA: University of California Press.

Hoffenberg, Peter H. (2003), "Photography and Architecture at the Calcutta International Exhibition”, in Maria Antonella Pelizzari (ed.), Traces of India. New Haven: Yale University Press, p. 178.

Kal, Hong (2005), "Modeling the West, Returning to Asia: Shifting Politics of Representation in Japanese Colonial Expositions in Korea", Comparative Studies in Society and History, 47(3), July, 507-531.

Lewis, Su Lin (2013), "Between Orientalism and Nationalism: The Learned Society and the Making of 'Southeast Asia", Modern Intellectual History, 10(2), 353-374.

Lima, José Joaquim Lopes de; Bordalo, Francisco Maria (1862), Ensaios sobre a estatística das possessões portuguesas na África Ocidental e Oriental, na Ásia Ocidental 
na China e na Oceania começados a escrever de ordem do governo de Sua Magestade. Lisboa: Imprensa Nacional.

Lobo, Sandra Ataíde (2013) O desassossego goês: cultura e política em Goa do liberalismo ao acto colonial. Doctoral Thesis, Faculdade de Ciência Sociais e Humanas da Universidade Nova de Lisboa, Lisboa, Portugal.

Maria Antonella Pelizzari (ed.) (2003), Traces of India: Photography, Architecture, and the Politics of Representation, 1850-1900. New Haven/London: Yale Center for British Art; Yale University Press; Canadian Centre for Architecture.

MacKenzie, John MacDonald (2009), Museums and Empire. Natural History, Human Cultures and Colonial Identities. Manchester: Manchester University Press.

McKeich, Cherie (2011), "Colonial Objects: T. N. Mukharji and Melbourne's Indian Collections”, in Deb N. Bandyopadhyay; Paul Brown; Christopher Conti (eds.), Landscape, Place and Culture: Linkages between Australia and India. Newcastle upon Tyne, England: Cambridge Scholars.

Nagpore Exhibition (1865), Report of the Nagpore Exhibition of Arts, Manufactures and Produce. Nagpur: Central Provinces Printing Press.

Nair, Janaki (2013), “Mysore's Wembley? The Dasara Exhibition's Imagined Economies", Modern Asia Studies, 47(5), 1549-1587.

Newman, Robert S. (2001), Of Umbrellas, Goddesses \& Dreams. Essays on Goa Culture and Society. Mapusa: Other India Press.

Noronha, Percival de (2000), "Indo-Portuguese Furniture and Its Evolution", in Charles J. Borges; Óscar G. Pereira; Hannes Stubbe (eds.), Goa and Portugal. History and Development. New Delhi: Concept Publishing, 183-196.

Perez, Rosa Maria (2011), The Tulsi and the Cross. Anthropology and the Colonial Encounter in Goa. Delhi: Orient Blackswan.

Pinto, Carla Alferes (2014), A colecção de arte colonial do Patriarcado de Lisboa. Proposta de estudo e musealização. Doctoral Thesis, Faculdade de Ciências Sociais e Humanas da Universidade Nova de Lisboa, Lisboa, Portugal.

Pinto, Rochelle (2007), Between Empires. Print and Politics in Goa. New Delhi: Oxford University Press.

Pope, Ethel (1989), India in Portuguese Literature. New Delhi: Asian Educational Services, [orig. ed. 1937].

Powell, John (1990), “Calcutta 1883-1884. Calcutta International Exhibition”, in John E. Findling (ed.), Historical Dictionary of World's Fairs and Expositions, 1851-1988. New York: Greenwood Press, 82-83.

Prakash, Gyan (1992), “Science 'Gone Native' in Colonial India”, Representations, 40, Autumn, p. 162.

Rice, Rebecca (2015), “A Red-letter Day: Evaluating Progress in New Zealand's Art at Dunedin's International Exhibitions, 1865 and 1889”, in Marta Filipová (ed.), Cultures of International Exhibitions 1840-1940. Farnham: Ashgate, 231-250. 
Souza, Teotónio Rosário de (1981), "The Voiceless in Goan Historiography. A Case for the Source-value of Church Records in Goa", in John Correia-Afonso (ed.), IndoPortuguese History. Sources and Problems. Bombay: Oxford University Press, 114-131.

Souza, Teotónio Rosário de (ed.) (1990), Goa Through the Ages: An Economic History, vol. II. New Delhi: Concept Publishing.

Tillotson, Giles (2004), “The Jaipur Exhibition of 1883”, Journal of the Royal Asiatic Society, 14(2), July, 111-126.

Trivedi, Lisa N. (2003), “Visually Mapping the 'Nation': Swadeshi Politics in Nationalist India, 1920-1930", The Journal of Asian Studies, 62(1), February, 11-41.

Vicente, Filipa Lowndes (2002), “A exposição do corpo sagrado de S. Francisco Xavier e as exposições industriais e agrícolas em Goa”, Oriente, 4, December, pp. 55-66.

Vicente, Filipa Lowndes (2003), "The Colonies on Display: Representations of the Portuguese Estado da Índia in Exhibitions Abroad”, Estudos do Século Xx, 3 , December, pp. 37-55.

Vicente, Filipa Lowndes (2012), Other Orientalisms. India Between Florence and Bombay, 1860-1900. New Delhi: Orient BlackSwan.

Vicente, Filipa Lowndes (ed.) (2014), "Viagens entre a Índia e o arquivo: Goa em fotografias e exposições”, O império da visão: fotografia no contexto colonial português (1860-1960). Lisboa: Edições 70, 319-342.

Vicente, Filipa Lowndes (2017), "Portuguese-speaking Goan Women Writers in Late Colonial India (1860-1940)”, Portuguese Studies Review, 25(1), 315-345.

Xavier, Ângela Barreto; Županov, Ines G. (2014), Catholic Orientalism. Portuguese Empire, Indian Knowledge: $16^{t h}-18^{\text {th }}$ Centuries. New Delhi: Oxford University Press.

Xavier, Francisco João (1876), Breve notícia da Imprensa Nacional de Goa seguida de um catálogo das obras e escritos publicados pela mesma imprensa desde a sua fundação. Nova Goa: Imprensa Nacional.

Received on 15.12.2017

Accepted for publication on 09.04.2018

\section{Filipa Lowndes Vicente}

Instituto de Ciências Sociais da Universidade de Lisboa Av. Prof. Aníbal Bettencourt, n. ${ }^{\circ}$ 9, 1600-189 Lisboa, Portugal

Contact: filipa.vicente@ics.ul.pt 
Goa exposta em Goa:

\section{A Exposição Industrial da Índia Colonial Portuguesa em 1860}

Em 1860, Goa foi o cenário de uma Exposição Industrial da Índia Portuguesa com 230 expositores e quase 4000 artigos expostos, todos descritos num catálogo impresso. Como é que se explica que Goa, considerada como a mais negligenciada das colónias portuguesas da segunda metade do século XIX, tenha tido uma "exposição industrial” cinco anos antes da primeira exposição internacional que teve lugar em Portugal, em 1865, e vinte anos antes da primeira exposição numa colónia, a de Cabo Verde em 1881? Este artigo analisa o significado de uma iniciativa local que expôs o passado, o presente e o futuro de Goa, um espaço que nos textos impressos da exposição era descrito como um "país" com uma identidade própria e distinta da "outra" Índia.

Palavras-chave: Exposição Industrial da Índia Portuguesa (1860); exposições; Goa; história de Goa; modernidade.

\section{Goa exposée à Goa: L'Exposition Industrielle de l'Inde Coloniale Portugaise en 1860}

En 1860, Goa fut le scénario d'une Exposition Industrielle de l'Inde Portugaise comptant 230 exposants et presque 4000 articles exposés, tous décrits dans un catalogue imprimé. Comment s'expliquer que Goa, tenue pour étant la plus négligée des colonies portugaises de la seconde moitié du XIX ${ }^{\mathrm{e}}$ siècle, ait accueilli une "exposition industrielle" cinq ans avant la première exposition internationale qui eut lieu au Portugal, en 1865, et vingt ans avant la première exposition dans une colonie, celle du Cap Vert en 1881? Cet article se penche sur la signification d'une initiative locale qui mit en exergue le passé, le présent et l'avenir de Goa, un espace qui dans les textes imprimés de l'exposition était décrit comme un "pays" ayant une identité propre et différente de 1'“autre" Inde.

Mots-clés: Exposition Industrielle de l'Inde Portugaise (1860); expositions; Goa; histoire de Goa; modernité. 
